\title{
Family Support and Family Economic Status With Depression Level on Patients End Stage Renal Disease
}

\author{
I Made Sundayana ${ }^{1}$, I Dewa ayu Rismayanti ${ }^{2}$, Putu Dian Prima Kusuma Dewi ${ }^{3}$, Muhith \\ Abdul $^{4}$, I Putu Gde Santika ${ }^{5}$, Lutfi K ${ }^{6}$ \\ \{madesundayana@gmail.com ${ }^{1}$, abdulmuhith@unusa.ac.id ${ }^{4}$ \} \\ Nursing Department of STIKES Buleleng ${ }^{1,2,3}$, Nursing Department, University of Nahdlatul Ulama \\ Surabaya ${ }^{4}$, Poltekkes RS dr Soepraoen Kesdam V/Brawijaya ${ }^{5}$, Student Nursing Department of STIKes \\ Majapahit Mojokerto ${ }^{6}$
}

\begin{abstract}
Patients with hemodialysis therapy have uncertainty as to how long hemodialysis is required and should accept the fact that therapy is needed throughout life. Because it appears anxiety response, rejection and anger. ESRD patients undergoing hemodialysis therapy, require support from the family. The purpose of this study was to determine the relationship of family support and economic status with depressed ESRD patients who underwent hemodialysis therapy <1 year. The design of this research is descriptive correlation with cross sectional research method, by using simple random sampling technique with the number of samples of 47 ESRD patients who are undergoing hemodialysis at Gatoel Hospital Mojokerto. The Research done in April 2017. The results obtained most of the respondents have economic ability Above the Provincial Minimum Wage of 27 respondents (57.4\%). Most of the respondents stated that they received good family support in 30 categories $(63,8 \%)$ and most of respondents had light depression 24 respondents $(51,1 \%)$. Based on statistical test of spearman's rho with significance level $\alpha$ 0,05 obtained result $(r)=0,462$ meaning bigger than value signifikansi $(0,462>0,05)$ hence $\mathrm{H} 1$ rejected which mean there is no significant relation between economic status with depression level In ESRD patients and Spearman's rho statistical test results obtained significance value $0.000<0.05$ which means there is a significant relationship between family support with depression levels in ESRD patients. The economic level does not affect depression because the cost of hemodialysis therapy all respondents is covered by health insurance, whereas family support has a positive influence where the better the family support the lighter the depression level in ESRD patients undergoing hemodialysis therapy.
\end{abstract}

Keywords: Family support, economic status, depression level, hemodialysis

\section{Intoduction}

End-stage renal failure is the rate of kidney failure that can cause death unless renal replacement therapy. Until now, Hemodialysis is still the main alternative to renal function replacement therapy for $\mathrm{CKG}$ patients because of the more accessible costs and the risk of bleeding lower when compared with peritoneal dialysis [1]. Hemodialysis action in chronic renal failure patients takes 12-15 hours for dialysis each week, or at least 3-4 hours of therapy interval. This activity will take place continuously throughout his life [1]. The state of 
dependence on hemodialysis machines results in changes in the life of ESRD sufferers undergoing hemodialysis therapy [2]. Not only have an impact on the economy, most patients with ESRD undergoing hemodialysis never return to their usual activity or occupation, resulting in a loss of employment, decreased income, loss of freedom, hope, self-esteem, and identity. The presence of a sense of loss, inadequate feelings, fear, and anxiety can lead to a mental disorder of depression.

In ESRD patients undergoing hemodialysis therapy, requires support from the family. Good emotional support, instrumental support, and information support. A person who gets support from the family will undergo hemodialysis with a passion [3]. Although the disease Kidney failure is not included in the ten deadly diseases in the world, the disease remains a concern of world health agencies. According to the World Health Organization (WHO), globally more than 500 million people suffer from chronic renal failure [4,5]. In Indonesia itself, according to Kidney Care Foundation there are 40.000 patients with chronic renal failure. But of that number, only about 3000 patients who usually enjoy the service of dialysis or hemodialysis [3]. Based on a preliminary study on December 72016 , recorded the number of patients who perform hemodialysis as many as 170 people. Based on interviews conducted on 10 patients who were diagnosed with medical End Stage Renal Disease (ESRD) and underwent hemodialysis less than 1 year found 3 of (10) $30 \%$ of patients have middle economic status with family support less likely to have severe depression level. And 7 out of 10 (10) $70 \%$ of patients with low economic status with good family support tend to have moderate levels of depression.

The state of dependence on hemodialysis machines results in changes in the life of ESRD sufferers undergoing hemodialysis therapy [2]. Not only have an impact on the economy, most patients with ESRD undergoing hemodialysis never return to their usual activity or occupation, resulting in a loss of employment, decreased income, loss of freedom, hope, self-esteem, and identity. There is a sense of loss, an inadequate feeling, fear, and anxiety that can lead to a mental disorder of depression [5] It is strongly associated with high mortality, high morbidity, and hospitalization (Kojima, 2012). ESRD patients undergoing hemodialysis usually start experiencing light to severe anxiety in the 2 nd to 6 th months, because at the beginning of the month the patient is still facing a stage of adjustment to hemodialysis action that must be done for the rest of his life [6]. Patients confronted with hemodialysis therapy have uncertainty as to how long hemodialysis is required and should accept the fact that hemodialysis therapy is required throughout life [6]. Because it appears anxiety response, rejection, and anger. It is a common response caused by stress that would have more impact on the state of depression [6].

At first, the patient will fall into anxiety state, anxiety that is not immediately overcome can bring the individual into the deeper psychological problems of depression, it will more impact on the final phase of the individual is the desire to end his life (suicide). In ESRD patients undergoing hemodialysis therapy, requires support from the family. Good emotional support, instrumental support, and information support. A person who gets support from the family will undergo hemodialysis with a passion (Anggraeni et al, 2016). Family support is an important factor for individuals when faced with health problems, in which families play a role in the health care function of their family members in order to achieve optimal health. Advice and affection from family members can provide a positive perception for individuals to achieve everything in reaching their dreams, so they are confident and optimistic about the future expectation. In addition, it is expected that sick family members can make the family as a collection of hope, where to tell, where to ask questions, and where to issue complaints when faced with problems [7].

Family support is an important factor for individuals when faced with health problems, in which families play a role in the health care function of their family members in order to achieve 
optimal health. Advice and affection from family members can provide a positive perception for individuals to achieve everything in reaching their dreams, so they are confident and optimistic about the future expectation. It is also expected that sick family members can make the family a collection of hope [8], where to tell, where to ask, and where to issue complaints when they are having problems. Support from the family can be an alternative to reduce depression levels, so the quality of life in patients with medical diagnoses End Stage Renal Disease who undergo hemodialysis therapy can be further improved. The purpose of this study was to determine the relationship of family support and economic status with depression levels in ESRD patients who underwent hemodialysis therapy less than 1 year in the Gatoel hospital Mojokerto District Indonesia.

\section{Method}

This research uses descriptive correlation with cross sectional research method. The population in this study were patients with a medical diagnosis of End Stage Renal Disease (ESRD) who underwent hemodialysis therapy in the Gatoel Hospital Mojokerto Indonesia. The sample of this research was 47 respondents taken using simple random sampling technique. This research was conducted at Gatoel Hospital of Mojokerto in April 2017. Data analysis in this study using Spearman rho statistical test. The instruments used in this study were the questionnaire sheet of Family Support, Economic Status, and Depression Rate.

\section{Result and Discussion}

\subsection{Economic status with level of depression in patients End Stage Renal Disease (ESRD) at Gatoel Hospital Mojokerto}

Table 1. Cross-tabulation of economic status with levels of depression in End Stage Renal Disease (ESRD) patients in Gatoel Hospital Mojokerto

\begin{tabular}{|c|c|c|c|c|c|c|c|c|c|c|c|}
\hline \multirow{3}{*}{ No } & \multirow{3}{*}{ Economic State } & \multicolumn{8}{|c|}{ Depression level } & \multirow{2}{*}{\multicolumn{2}{|c|}{ Total }} \\
\hline & & \multicolumn{2}{|c|}{ Heavy } & & rate & \multicolumn{2}{|c|}{ Light } & \multicolumn{2}{|c|}{ Normal } & & \\
\hline & & $\mathrm{f}$ & $\%$ & $\mathrm{f}$ & $\%$ & $\mathrm{f}$ & $\%$ & $\mathrm{f}$ & $\%$ & $\mathrm{f}$ & $\%$ \\
\hline 1 & $\leq$ Minimum wage & 2 & 10 & 5 & 25 & 11 & 55 & 2 & 10 & 20 & 100 \\
\hline \multirow[t]{3}{*}{2} & $>$ Minimum wage & 3 & 11,1 & 5 & 18,5 & 13 & 48,1 & 6 & 22,2 & 27 & 100 \\
\hline & Total & 5 & 10,6 & 10 & 21,3 & 24 & 51,1 & 8 & 17 & 47 & 100 \\
\hline & \multicolumn{11}{|c|}{ Significant value of spearman's rho test $=0,462$} \\
\hline
\end{tabular}

The above results show that from 20 respondents who have economic capability less or equal to minimum wage ( $\operatorname{Rp} 1.388 .000)$, most of them are experiencing light depression that is 11 respondents $(55 \%)$ while 27 respondents have economic ability above minimum wage (Rp $1,388,000)$ was obtained almost half of the light depression that is 13 respondents $(48,1 \%)$. After knowing the result of cross-tabulation table then done the calculation by using Spearman's rho with a level of significance value $\alpha: 0,05$. Spearman's rho test results obtained significance value $0.462<0.05$ which means there is no significant relationship between economic status with depression level in patients End Stage Renal Disease (ESRD) in Gatoel Hospital Mojokerto. 
These values are the ability of respondents in meeting the needs of everyday life, especially the needs of clothing, food, and boards. Economic status is the position of a person or family in the community based on income per month. Economic status can be seen from the income adjusted to the price of staple goods (Anita 2013). Factors affecting the economic level of individuals, including education, employment, economic circumstances, cultural background, and income. Work is a means to earn money in order to meet the needs of life, including the desired health services (Muhith, 2014). In those who experience End Stage Renal Disease (ESRD) costs approximately Rp. 8.000 .000 per month to undergo hemodialysis therapy perceived their income is still very less. Still very far to cover medical expenses. But with the health insurance, they are very helpful, because $100 \%$ of the cost of hemodialysis therapy is borne by the insurance. So they no longer need to worry about the cost of therapy is not a little every week, the patient just needs to think about other costs such as accommodation costs.

The results of the study did not show the relation of an economic level with the depressed patient level of End Stage Renal Disease (ESRD). It can be explained that income is not even able to make a person happy or not depressed if they experience pain, especially late-stage illness. For all respondents, money seems meaningless and will surely run out no matter how much money if the illness does not heal. Moreover, hemodialysis therapy is not for treatment or healing, but rather to maintain the life of the patient. They sometimes feel the therapy experienced is just useless. One factor that keeps them on hemodialysis therapy is because the cost of hemodialysis therapy is covered by health insurance, so they are quite helped by the health insurance program.

\subsection{Family support with level of depression in End Stage Renal Disease (ESRD) patients in the Gatoel Hospital Mojokerto}

Table 5. Cross-tabulation of family support with level of depression in End Stage Renal Disease (ESRD) patients in the Gatoel Hospital Mojokerto

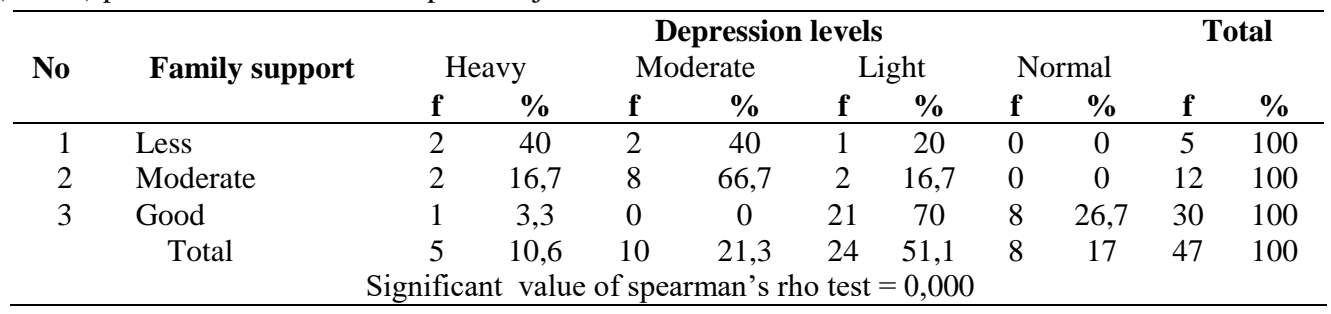

The table above shows that 12 respondents who claimed to get enough support from the family, most of them had moderate depression, which was 8 respondents $(66.7 \%)$. Whereas from 30 respondents who claimed to get good support from the family found most experienced a mild depression that is as much as 21 respondents (70\%). After knowing the result of a crosstabulation table then done the calculation by using Spearman's rho with a level of significance value $\alpha$ : 0,05 . Spearman's rho test results obtained significance value $0.000<0.05$ which means there is a significant relationship between family support with depression level in patients End Stage Renal Disease (ESRD) in RS. Gatoel Mojokerto. The relationship is in a strong category (0.728) and positive which means the better the family supports the more normal the level of depression the patient end Stage Renal Disease (ESRD).

Family support is a form of attention, encouragement that individuals get from others through interpersonal relationships that include attention, emotional and judgment (Anggita, 
2016). In ESRD patients undergoing hemodialysis therapy, requires support from the family. Good emotional support, instrumental support, and information support. A person who gets support from the family will undergo hemodialysis with passion (Anggraeni et al, 2016). For long treatment requires patience and encouragement from his family. Many patients are saturated with the disease because of treatment. The family is seen as an important area of the client and therefore the family is the greatest support to the client. Families who care about health, will pay attention to their families very well (Muhith, 2015). Support provided by the family can be identified through a questionnaire of research results. Based on the emotional support and appreciation that most of the respondents said his family always loved and paid attention to the state of the patient during illness.

\section{Conclussion}

Based on the results of the study titled Relation of family support and economic status with depression levels in patients with End Stage Renal Disease (ESRD) who underwent hemodialysis therapy less than 1 year in the hospital. Gatoel Mojokerto on 47 respondents can be concluded research results as follows:

1. Most respondents have economic capability above Provincial Minimum Wage (UMP).

2. Most respondents claimed to have family support in either category.

3. Most of the respondents had mild depression.

4. Spearman's rho test results indicate no significant relationship between economic status and depression level in End Stage Renal Disease (ESRD) patient in the hospital. Gatoel Mojokerto

5. Spearman's rho test results showed no significant association between family support and depression levels in patients with End Stage Renal Disease (ESRD) in hospitals. Gatoel Mojokerto. The relationship is in the strong and positive category which means the better the family support the more normal the depression level of patients End Stage Renal Disease (ESRD)

\section{Reference}

[1] Jhoni Y.K. Jangkup, dkk. (2015). Tingkat Kecemasan Pada Pasien Penyakit Ginjal Kronik (PGK) Yang Menjalani Hemodialisis di BLU RSUP Prof. Dr. D. Kandou Manado.Jurnal e-clinic Vol. 3 No. 1

[2] Anggita Yuliani, P., dkk. (2016) . Hubungan Dukungan Keluarga Terhadap Tingkat Depresi pada Pasien Gagal Ginjal Kronik Di Ruang Hemodialisis Di RSUD Tugurejo Semarang.

[3] Anggraini Rostanti, dkk. (2016). Faktor-faktor Yang Berhubungan Dengan Kepatuhan Menjalani Terapi Hemodialisis Pada Penyakit Ginjal Kronik Di Ruangan Dahlia Dan Melati RSUP Prof. Dr. R.D. Kandou Manado. Jurnal Keperawatan Vol. 4 No. 2

[4] Muhith, A. (2015). Pendidikan Keperawatan Jiwa (Teori dan Aplikasi). Yogyakarta: Andi. .

[5] Muhith, A., fardiansyah A., Saputra, M.H., Nurmiyati (2018). Analisis of causes Impacts of Early Marriage on Madurese Sumenep East Java Indonesia. Medicine: Public health, Evironmental and Occupational Health. Indian Journal of Public health Research \& Development. Volume. 9 Number 8. First page 412-416. (08 Agustus 2018), ISSN 0978-0245 (print), ISSN 0976-5506 (Electronic). DOI Number: 10.5958/0976-5506.2018,00944.0. 
[6] Ainivi F. Tangian, dkk. (2015). Hubungan Lamanya Menjalani Hemodialisis Dengan Tingkat Kecemasan Pada Pasangan Hidup Pasien Yang Menderita Penyakit Ginjal Kronik Di RSUP Prof. Dr. R.D. Kandou Manado. Jurnal e-Clinic Vol. 3 No. 1

[7] Muhith A., et al (2018). The spatial patten and risk factors of leprosy occurence in barru indonesia. Medicine: Public health, Evironmental and Occupational Health. Indian Journal of Public health Research \& Development. Volume. 9 Number 8. First page 1489-1494. (08 Agustus 2018), ISSN 0978-0245 (print), ISSN 0976-5506 (Electronic). DOI Number: 10.5958/0976-5506.2018,00943.9.

[8] Muhith A., dkk (2018). The spatial patten and risk factors of leprosy occurence in barru indonesia. Medicine: Public health, Evironmental and Occupational Health. Indian Journal of Public health Research \& Development. Volume. 9 Number 8. First page 1489-1494. (08 Agustus 2018), ISSN 0978-0245 (print), ISSN 0976-5506 (Electronic). DOI Number: 10.5958/0976-5506.2018,00943.9. 